\title{
Child and Parent Characteristics Associated With Canadian Parents' Reports of Spanking
}

\author{
Jeff L. Perron, Catherine M. Lee, and Kathryn J. LaRoche \\ University of Ottawa \\ Christine Ateah \\ University of Manitoba \\ Marie-Ève Clément \\ Université du Québec en Outaouais
}

Kathy Chan

University of Ottawa

\begin{abstract}
We examined self-reported use of spanking as a discipline strategy in a Canadian sample of mothers and fathers $(N=2,340)$ of children aged 2 to 12 years using data from the International Parenting Survey-Canada. Logistic regression was conducted to assess the association between reported use of spanking and child characteristics (age, gender, disability status, and behaviour problems), adult demographic characteristics (age at birth of child, marital status, education, employment, and income inadequacy), as well as parent attitudes toward spanking. Approximately one quarter of parents reported spanking their child. Child age, parent education, employment, and income inadequacy had significant associations with reported spanking. When controlling for child and parent demographic characteristics, parent reports of child behaviour and parent attitudes toward spanking also had strong relationships with reported spanking. Results are discussed in relation to previous findings and in terms of implications for parenting interventions.
\end{abstract}

Keywords: spanking, discipline, parenting, corporal punishment, survey

Jeff L. Perron, School of Psychology, University of Ottawa; Catherine M. Lee, School of Psychology, University of Ottawa; Kathryn J. LaRoche, School of Psychology, University of Ottawa; Christine Ateah, Faculty of Nursing, University of Manitoba; Marie-Ėve Clément, Canadian chair on violence against children, Département de psychoéducation et psychologie, Université du Québec en Outaouais; Kathy Chan, School of Psychology, University of Ottawa.

Special thanks are due to the parents who completed the survey. We appreciate the work of Whitney Taylor in data cleaning and are grateful to Dr. Dwayne Schindler for statistical consultation. We are grateful to the developers of the International Parenting Survey, Drs. Alina Morawska, Nina Heinrichs, and Matthew Sanders.

Correspondence concerning this article should be addressed to Jeff L. Perron, School of Psychology, University of Ottawa, Ottawa, ON K1N 6N5. Email: JPerr101@uOttawa.ca 


\section{RÉSUMÉ}

Le recours à la fessée comme une stratégie disciplinaire a été analysé dans un échantillon canadien des mères et des pères $(N=2340)$ d'enfants âgés de 2 à 12 ans à partir des données de l'Enquête internationale auprès des parents - Canada. Une analyse de régression logistique a été réalisée afin d'évaluer l'association entre la fessée d'une part et, d'autre part, les caractéristiques de l'enfant (âge, sexe, état de handicap et problèmes de comportement), les caractéristiques démographiques des parents (âge à la naissance de l'enfant, état matrimonial, niveau d'éducation, statut d'emploi et insuffisance du revenu) et les attitudes parentales envers la fessée. Environ un quart des parents ont déclaré avoir recours à cette méthode disciplinaire envers leur enfant. L'âge de l'enfant, le niveau d'éducation des parents, leur statut d'emploi, et leur revenu sont significativement associées au recours autodéclaré à la fessée. Le comportement de l'enfant et les attitudes parentales sont également fortement associés au recours à la fessée. Les résultats sont discutés en relation avec ceux d'études antérieures et en termes d'implications pour les interventions parentales.

Mots clés : fessée, discipline, rapports parents-enfants, châtiment corporel, enquête

Physical or corporal punishment has been defined as the use of physical force toward a child that causes the child to experience pain, but not injury, for the purposes of correction or control of behaviour (Straus \& Donnelly, 1993). In many parts of the world, spanking has been a common and widely accepted form of physical punishment of children (Durrant \& Ensom, 2012). Although an increasing number of countries have made corporal punishment illegal (Global Intiative to End the Corporal Punishment of Children, 2013), it is permitted in the United States and in Canada within certain parameters (Bell \& Romano, 2012; Ferguson, 2013).

Research over the last 30 years has examined negative child outcomes of physical punishment. For example, Gershoff (2002) reported on a meta-analysis of 88 studies that found associations between the use of parental physical punishment and a number of negative developmental outcomes such as child aggression, child mental health issues, and poorer quality of relationship between parent and child. Other researchers (e.g., Ferguson, 2013; Larzelere, Cox, \& Smith, 2010) have raised methodological criticisms of this body of research and argue that there are also negative outcomes associated with nonphysical disciplinary responses. However, there are no studies that have found that physical punishment enhances developmental health in children or has a long-term positive effect (Durrant \& Ensom, 2012).

Not only is a clear definition of spanking important to research attempting to clarify its long-term effects, so too is an understanding of the frequency of spanking among parents in North America and worldwide. Many retrospective studies have found that the majority of Canadian adults report having experienced physical punishment during their childhood (e.g., Ateah \& Parkin, 2002; Gagné, Tourigny, Joly, \& Pouliot-Lapointe, 2007).

The rates of self-reported physical punishment in the United States and Canada have been consistently higher than those reported in Central Europe and Scandinavia (Durrant, Rose-Krasnor, \& Broberg, 2003). However, self-reported use of spanking is declining among Canadian (e.g., Clément, Bernèche, Chamberland, \& Fontaine, 2013; Fréchette and Romano, 2012) and American (e.g., Zolotor, Theodore, Runyan, Chang, \& Laskey, 2011) parents. In their study of 110 mothers of 3-year-old children, Ateah and Durrant (2005) found $59.1 \%$ of participants reported physically punishing their children in the 2-week period prior to data collection. Fréchette and Romano (2012) underlined that Statistics Canada data from 1994 indicated that nearly 
$50 \%$ of parents of children aged 2-11 years reported having, at some point in the past, physically punished their child, whereas by 2008, this rate had fallen to approximately 25\%. Clément et al. (2013) reported that in a sample of parents of children aged 6 months to 17 years residing in Quebec, $14.5 \%$ of parents reported spanking their child at least once in the past year.

\section{Child and Parent Characteristics Associated With Spanking}

In addition to analyzing its frequency, researchers have examined child and parent characteristics that may be associated with spanking. A clearer understanding of these characteristics may elucidate circumstances under which spanking is used as well as identify the most suitable approach in efforts to encourage the use of alternative parenting strategies (MacKenzie, Nicklas, Brooks-Gunn, \& Waldfogel, 2011).

Child characteristics. Studies have consistently found that parents of preschool-aged children are more likely to report spanking than are parents of older children (Day, Peterson, \& McCracken, 1998; Giles-Sims, Straus, \& Sugarman, 1995; Grogan-Kaylor \& Otis, 2007; Regalado, Sareen, Inkelas, Wissow, \& Halfon, 2004). Two large-scale U.S. studies yielded less clear findings with respect to child gender. Day et al. (1998) found that among both mothers and fathers of children aged 1-11, parents of boys reported spanking more frequently than did parents of girls. MacKenzie et al. (2011), however, found that among Black families with children aged 3 and 5 years, mothers of sons were more likely to report spanking than were mothers of daughters, but there were no child gender differences among other ethnic groups. Only one study has examined parental reports of spanking children with disabilities. Regalado et al. (2004) found that parents of children at risk of developmental delay were more likely to report that they spanked the child than were parents whose child was not at risk of developmental delay.

Research has consistently found higher rates of self-reported spanking among parents who report that their child's behaviour is problematic than among parents whose child's behaviour is not reported as problematic (Berlin et al., 2009; Grogan-Kaylor \& Otis, 2007; Lee, Taylor, Altschul, \& Rice, 2013; MacKenzie et al., 2011; Maguire-Jack, Gromoske, \& Berger, 2012; Stormshak, Bierman, McMahon, \& Lengua, 2000). In addition, some studies have found that specific types of problematic behaviours such as difficult or defiant temperaments are more closely tied to spanking than are other types (e.g., Mulvaney \& Mebert, 2007).

Parent characteristics. Research has consistently found that in samples of parents with very young children, younger parents are more likely to spank their children than are older parents (e.g., MacKenzie et al., 2011; Regalado et al., 2004; Wissow, 2001). This finding has been reported in samples of mothers of children aged 3-5 years (MacKenzie et al., 2011) and in samples that included both mothers and fathers of children aged 0-3 years (Regalado et al., 2004; Wissow, 2001). However, Grogan-Kaylor and Otis (2007) found no significant association between parent age and reported spanking in a sample in which the average age of children was 9 years. Of note, few studies account for parent age at the birth of the target child. Not accounting for parenting age at birth of the child may confound the age of the child with the age of the parent.

The effect of parent gender on self-reported spanking is unclear. Wissow (2001) found no difference between mothers and fathers in their likelihood of reporting spanking their child. However, Day et al. (1998) found that fathers were less likely to report spanking than were mothers. Differences in rates of spanking between mothers and fathers could be influenced by the amount of time parents spend with their children. 
Studies of the relationship between marital status and the use of spanking (e.g., Day et al., 1998; GilesSims et al., 1995; Wissow, 2001) have yielded diverse findings. Giles-Sims et al. (1995) found that single parents who reported spanking said that they did so more frequently (more times per week) than did married parents who spank. Day et al. (1998) found that single Black mothers reported spanking more frequently than did married Black mothers. They posited, however, that this finding may be related to single parents being younger than married parents in their sample. Wissow (2001), with a sample of parents of children aged 0-3 years, found no marital status-related differences in reports of spanking.

Most studies that examined parent education found it was not associated with self-reported spanking (Giles-Sims et al., 1995; Grogan-Kaylor \& Otis, 2007; Regalado et al., 2004). An exception is the study by Wissow (2001) that found that less educated parents were more likely to report spanking their child than were more highly educated parents. Contradictory findings have been reported with respect to employment. Giles-Sims et al. (1995) found that mothers who reported sporadic employment reported higher rates of spanking than did mothers who were employed full-time, whereas other studies (MacKenzie et al., 2011; Wissow, 2001) reported no link between employment and reported use of spanking. Income has been found to be inversely related to use of spanking (e.g., Giles-Sims et al., 1995). However, Wissow (2001) found that the relationship between spanking and family income was not linear. That is, parents with annual incomes below $\$ 20,000$ or above $\$ 60,000$ were less likely to report spanking than were parents who earned an income within that bracket. Notably, studies that have examined the association between family income and spanking (e.g., Giles-Sims et al., 1995; MacKenzie et al., 2011; Wissow, 2001) have measured family income in different earning brackets. No studies have examined whether the sufficiency of income to pay for essential expenses is associated with differing reports of spanking.

Many studies have found higher rates of self-reported spanking among Black parents than among White parents (Day et al., 1998; Gershoff, Lansford, Sexton, Davis-Kean, \& Sameroff, 2012; Grogan-Kaylor \& Otis, 2007; MacKenzie et al., 2011; Regalado et al., 2004; Wissow, 2001). However, in a longitudinal study, Lansford, Wager, Bates, Dodge, and Pettit (2012) found no differences in the frequency with which White and Black mothers reported spanking their children. The majority of research that has examined racial and ethnic differences in spanking has used samples recruited in the United States (e.g., Lansford et al., 2012; MacKenzie et al., 2011; Regalado et al., 2004). Much less is known about reported use of spanking across diverse racial and ethnic groups in Canada.

There is consistent evidence that more favourable attitudes toward spanking are associated with a higher incidence of spanking (e.g., Ateah \& Durrant, 2005; Holden, Coleman, \& Schmidt, 1995; Pinderhughes, Dodge, Bates, Pettit, \& Arnaldo, 2000; Vittrup, Holden, \& Buck, 2006). For example, in a sample of mothers, Ateah and Durrant (2005) found that approval of spanking was the variable that most strongly predicted its use. Of note, Vittrup et al. (2006) found that attitudes toward spanking persisted over time.

\section{Gaps in Current Knowledge}

Research into child characteristics related to spanking shows that there are clear patterns with respect to child age and behaviour. Among adult characteristics, there is clear evidence that in samples with very young children, younger parents are more likely to spank; however, this finding may be confounded with 
child age. For example, spanking is more likely the younger the parent, the younger the child, and the less experienced the parent. Research on the association between spanking and child gender, parent gender, parent marital status, education, employment, income, and ethnicity has also yielded conflicting findings.

The nature of the samples should be taken into account in the interpretation of past research and the planning of future research. Many spanking-related studies have focused solely on children between birth and 24 months (e.g., Holden et al., 1995; MacKenzie et al., 2011; Regalado et al., 2004; Vittrup et al., 2006; Wissow, 2001). As Canadian law permits the use of spanking of children aged 2-12 within parameters (Criminal Code of Canada, 2008, p. 1), it is essential to examine patterns of spanking in samples of families with children in that age range.

Like much of the literature on parenting, samples used in studies of spanking are composed primarily of mothers (e.g., Giles-Sims et al., 1995; MacKenzie et al., 2011; Regalado et al., 2004). A notable exception is a study on the impact of fathers' experiences and beliefs about physical punishment (see Jamal, Dufour, Clément, \& Chamberland, 2011). It is important to include fathers in studies of spanking. The vast majority of research on spanking has been conducted outside of Canada (Ferguson, 2013; Gershoff, 2002). It is unclear whether American findings can be generalized to Canadian parents. Further, societal attitudes toward spanking and the frequency of its use have changed over time (e.g., Bell \& Romano, 2012; Clément et al., 2013; Durrant \& Ensom, 2012). Given these temporal changes, it is important to regularly assess the use of spanking and associated child and parent characteristics.

\section{The Current Study}

This study was designed to examine the percentage of Canadian parents of children aged 2-12 who report using spanking to discipline their children. We also planned to examine whether self-reported spanking was associated with (a) child characteristics including age, gender, disability, and behaviour problems as well as (b) parent characteristics including gender, age at birth of child, marital status, education, employment, income inadequacy, ethnicity, and attitudes toward spanking.

Based on previous research we predicted that (a) self-reported spanking would be negatively associated with child age (the younger the target child, the more likely the parent would be to report spanking); (b) there would be a positive association between self-reported spanking and parent ratings of child behavioural difficulties (the higher the behavioural difficulties, the more likely parents would be to report spanking); (c) there would be a negative association between self-reported spanking and parent age at birth of target child (the younger parents are at the birth of the target child, the more likely they would be to report spanking); (d) there would be a negative association between self-reported spanking and income inadequacy (parents who report that at some time during the past 12 months their income was inadequate to pay for necessary expenses will be more likely to report spanking than parents who do not report income inadequacy); and (e) there would be a positive association between self-reported spanking and endorsement of pro-spanking beliefs (the greater the extent to which parents endorsed pro-spanking beliefs, the more likely parents would be to report spanking).

In addition, we planned to examine the relationship between reported spanking and a number of variables that have not yielded consistent findings: child gender and disability status; and parent gender, marital status, education, employment, and ethnicity. For these variables, we did not make directional hypotheses. 


\section{METHOD}

Data from the Canadian arm of the International Parenting Survey were utilized (see Lee et al., 2014). Twenty-nine agencies from the provinces of Alberta, Ontario, Prince Edward Island, and Quebec facilitated data collection.

\section{Measures}

Parents were asked to complete a questionnaire with respect to their youngest child in the $2-12$ age range. Parents were first asked their child's age and gender ( $0=$ male; $1=$ female $)$ as well as the child's disability status $(0=$ child does not have a chronic disability; $1=$ child has a chronic disability). To avoid issues of multicollinearity between parent age and child age, we calculated parents' age at the birth of the target child. Parents were also asked about their gender $(0=$ male; $1=$ female $)$, marital status $(0=$ married/ cohabiting; $1=$ divorced/separated, single, widow/er $)$, highest level of education $(0=$ high school or less; $1=$ trade/technical college; $2=$ university or postgraduate degree), employment $(0=$ full-time; $1=$ part-time; $2=$ not working for pay; 3 =home-based paid work), income inadequacy, and ethnicity. Income inadequacy was assessed by the question, "During the past 12 months, has there been a time when your household could not meet its essential expenses?" $(0=$ yes; $1=$ no $)$; ethnicity was recorded using Statistics Canada's categories $(0=$ White; 1 = ethnic minority).

Spanking. Spanking was assessed using an item from the Parenting and Family Adjustment Scales (PAFAS; Sanders, Morawska, Haslam, Filus, \& Fletcher, 2014). The PAFAS includes 28 items that describe parenting practices, including "I spank (smack) my child when they misbehave." Parents are required to rate a 4-point Likert scale from not at all (0) to very much or most of the time (3) to indicate the extent to which the item applies to them over the past 4 weeks. Participant responses on this item were dichotomized. Parents who reported that they spanked their child not at all were assigned a 0 . Parents who reported spanking their child a little (some of the time), quite a lot (a lot of the time), or very much or most of the time were assigned a 1. Responses were dichotomized to include in the spanking group parents who had engaged in any type of spanking in the past month.

Child behavioural adjustment. Parents completed the Child Adjustment and Parental Efficacy Scale (CAPES; Morawska \& Sanders, 2010). The CAPES includes 30 items assessing behavioural adjustment that parents are asked to rate on a 4-point Likert scale from not true of my child at all (0) to true of my child very much or most of the time (3) the extent to which the item applies to them over the past 4 weeks. A sample item is "yells, shouts or screams." Higher scores indicate a greater number of problems. Morawska and Sanders (2010) reported excellent internal consistency for behavioural adjustment (.91). In the current sample, comparable alpha coefficients were obtained for behavioural adjustment (.91 overall, .90 in English, .89 in French, .91 for fathers, .90 for mothers).

Attitudes toward spanking. Participants completed the 4-item Spanking Acceptability Subscale of the Parenting Belief Scale (Faruggia, 2009). Parents were asked to rate on a 5-point Likert scale their agreement with statements representing attitudes toward physical punishment. Sample items included "As long as it doesn't leave a mark, smacking/spanking your child is not a big deal," and "Sometimes smacking/spanking 
children is the only way to make them understand." Scores on the four items were summed to create a spanking acceptability score for each participant. Items on this subscale yielded good internal consistency (.89 overall, .90 for English, .88 for French, .92 for fathers, .89 for mothers).

\section{Participant Recruitment}

Partner agencies solicited potential participants through notices on their websites, in electronic bulletins and newsletters, and through posters in their facilities. These posters and notices provided the internet link necessary for participants to complete the survey online at a time of the participants' choosing. When requested, partner agencies were also sent paper copies of the survey, which they handed out to interested participants. The completed paper surveys were returned to the University of Ottawa in a sealed envelope, where a research assistant entered the survey responses online. Recruitment was conducted between April 2012 and April 2013. This study received approval from the research ethics board of the University of Ottawa as well from the universities of all coinvestigators.

\section{Participants}

In total, 2,340 parents and other caregivers with at least one child aged 2-12 completed the survey. In this sample, $25.5 \%$ of parents of children aged 2-12 reported spanking their child a little (some of the time) or more frequently.

Table 1 presents demographic characteristics for the sample, organized according to parents who did and did not report spanking. The average age of target children was 5.6 years. The average age of parents was 36.7 years. The sample was made up primarily of mothers $(91.3 \%)$. As the ratio of mothers to fathers was greater than 9:1, no analyses were undertaken on parent gender (Tabachnik \& Fidell, 2007). As the sample for the International Parenting Survey-Canada was a convenience sample, it is important to consider the extent to which it is representative of the Canadian population. The proportion of parents in a couple relationship (married or common-law, 85.4\%) is comparable to the proportion of couple-headed families in the 2011 Census (83.7\%; Statistics Canada, 2012a). Compared to Canadian women aged 25-34, the parents in the sample had a slightly higher level of education than would be expected from census data (Statistics Canada, 2012a). Rates of various employment types (55.7\% of the sample reported being employed fulltime and $18.0 \%$ part-time) were also comparable to population-level statistics (Statistics Canada, 2009). Although the measure of income inadequacy does not have a readily available population-level comparator, the fact that one fifth of parents reported that there had been a time in the past year when their income was inadequate to meet essential expenses is in line with UNICEF's estimation that $15.1 \%$ of Canadian children live in poverty (UNICEF Innocenti Research Centre, 2012). The ethnic composition of the sample included an overrepresentation of White parents (89.6\%) and an underrepresentation of other ethnic backgrounds and Aboriginal parents. Therefore, the sample did not permit further examination of ethnicity. Similarly, only $9 \%$ of the sample reported having been born outside of Canada. This is low compared to the $20.6 \%$ of the general Canadian population (Statistics Canada, 2012a). The sample underrepresents the proportion of Canadians whose first language is French (22\%; Statistics Canada, 2012b), as only 10\% of participants reported French as their first language. 
Table 1

Child and Parent Characteristics of Parents Who Did and Did Not Report Spanking

\begin{tabular}{|c|c|c|c|c|c|c|}
\hline \multirow[t]{2}{*}{ Characteristic } & \multicolumn{2}{|c|}{ No spanking } & \multicolumn{2}{|c|}{ Spanking } & \multicolumn{2}{|c|}{ Total } \\
\hline & $n$ & $\%$ & $n$ & $\%$ & $n$ & $\%$ \\
\hline \multicolumn{7}{|l|}{ Child } \\
\hline \multicolumn{7}{|l|}{ Gender } \\
\hline Male & 912 & 74.7 & 308 & 25.3 & 1,220 & 52.3 \\
\hline Female & 826 & 74.2 & 287 & 25.8 & 1,113 & 47.7 \\
\hline \multicolumn{7}{|l|}{ Disability status } \\
\hline No & 1,348 & 74.5 & 457 & 25.5 & 1,805 & 78.0 \\
\hline Yes & 380 & 74.7 & 130 & 25.3 & 510 & 22.0 \\
\hline \multicolumn{7}{|l|}{ Parent } \\
\hline \multicolumn{7}{|l|}{ Gender } \\
\hline Male & 139 & 69.8 & 60 & 30.2 & 199 & 8.7 \\
\hline Female & 1,573 & 74.9 & 527 & 25.1 & 2,100 & 91.3 \\
\hline \multicolumn{7}{|l|}{ Marital status } \\
\hline Married/cohabitating & 1,484 & 74.4 & 510 & 25.6 & 1,994 & 85.4 \\
\hline Single, divorced, or widow(er) & 255 & 75.0 & 85 & 25.0 & 340 & 14.6 \\
\hline \multicolumn{7}{|l|}{ Highest level of education } \\
\hline High school & 240 & 63.7 & 137 & 36.3 & 377 & 15.8 \\
\hline Trade/technical college & 552 & 71.9 & 216 & 28.1 & 768 & 32.2 \\
\hline University & 998 & 79.5 & 239 & 20.5 & 1,237 & 51.9 \\
\hline \multicolumn{7}{|l|}{ Employment } \\
\hline Full-time & 1,019 & 79.1 & 269 & 20.9 & 1,288 & 55.7 \\
\hline Part-time & 295 & 71.2 & 120 & 28.8 & 415 & 18.0 \\
\hline Not working for pay & 336 & 65.9 & 174 & 34.1 & 510 & 22.1 \\
\hline Paid work from home & 69 & 70.4 & 29 & 29.6 & 98 & 4.2 \\
\hline \multicolumn{7}{|l|}{ Income inadequacy } \\
\hline Yes & 1,414 & 76.5 & 434 & 23.5 & 1,848 & 80.0 \\
\hline No & 307 & 66.1 & 157 & 33.9 & 464 & 20.0 \\
\hline \multicolumn{7}{|l|}{ Ethnicity } \\
\hline White & 1,547 & 74.9 & 518 & 25.1 & 2,065 & 89.6 \\
\hline Non-white & 168 & 70.3 & 71 & 29.7 & 239 & 10.4 \\
\hline
\end{tabular}

Note. Total number of parents who reported not spanking was 1,742 (74.5\%). The number of parents who reported spanking was $595(24.5 \%)$. These totals do not equal $N=2,340$ due to missing data. 


\section{Statistical Analyses}

All analyses were conducted using SPSS version 19. Bivariate analyses include Pearson correlations between the dichotomous variable of parent reports of spanking and all variables, with the exception of parent education and parent employment status (as they are not ordinal variables). The correlation matrix is presented in Table 2. Chi-square analyses were conducted on parent education and parent employment status.

To examine the combined influence of these variables, a logistic regression was conducted to predict spanking. Three blocks were used in the regression. We grouped demographic variables in Block 1. The second block included parent ratings of child behaviour. Based on past research by Ateah and Durrant (2005), we predicted that much of the variance would be explained by the attitude-toward-spanking variable, and therefore we entered this variable last, in a separate block (Block 3).

\section{RESULTS}

Table 2 shows that reports of spanking were significantly correlated with demographic variables such as child age, parent age at child's birth, and income inadequacy, as well as with child behaviour and parental attitudes toward spanking. Chi-square analyses revealed that education $\left(\chi^{2}(2, N=2,312)=41.46, p<.001\right)$ and employment status $\left(\chi^{2}(3, N=2,311)=37.67, p<.001\right)$ were also significantly associated with spanking. The results of the hierarchical logistic regression are presented in Table 3 . The model was statistically significant, indicating that child and parent demographic variables, child behaviour, and parent attitudes, as a set, reliably distinguished between parents who reported spanking and parents who did not report spanking $\left(\chi^{2}(13, N=2,237)=938.15, p<.001\right)$.

\section{Table 2}

Intercorrelations for Spanking and Predictor Variables

\begin{tabular}{|c|c|c|c|c|c|c|c|c|c|}
\hline Variable & 1 & 2 & 3 & 4 & 5 & 6 & 7 & 8 & 9 \\
\hline 1. Spanking & -- & & & & & & & & \\
\hline 2. Child age & $-.14^{* *}$ & -- & & & & & & & \\
\hline 3. Child gender & .01 & .02 & -- & & & & & & \\
\hline 4. Disability status & .00 & $.11^{* *}$ & .01 & -- & & & & & \\
\hline 5. Parent age at birth of child & $-.06^{* *}$ & $.12^{* *}$ & .01 & .01 & -- & & & & \\
\hline 6. Parent marital status & -.01 & $.06^{* *}$ & .00 & $.07^{* *}$ & $-.09^{* *}$ & -- & & & \\
\hline 7. Income inadequacy & $.10^{* *}$ & $-.05^{*}$ & .02 & $.10^{* *}$ & $-.10^{* *}$ & $-.19^{* *}$ & -- & & \\
\hline 8. Child behaviour & $.19^{* *}$ & $-.11^{* *}$ & -.01 & $-.19^{* *}$ & $-.04^{* *}$ & $.10^{* *}$ & $.13^{* *}$ & -- & \\
\hline 9. Parental attitudes & $.59^{* *}$ & -.03 & .01 & .01 & $-.06^{* *}$ & .02 & $.12^{* *}$ & $.13^{* *}$ & -- \\
\hline
\end{tabular}

Note. ${ }^{*} p<.05 . * * p .01$. 
Table 3

Summary of Logistic Regression Analysis Examining Child and Parent Characteristics Associated With Reported Spanking

\begin{tabular}{|c|c|c|c|c|c|c|c|c|c|}
\hline Block and variable & $R^{2}$ & $\Delta R^{2}$ & $B$ & $S E$ & $O R$ & $95 \% \mathrm{CI}$ & $p$ & $\begin{array}{l}\text { Wald } \\
\text { statistic }\end{array}$ & VIF \\
\hline Block 1 & .07 & .07 & & & & & & & \\
\hline Child age & & & -.10 & .02 & .91 & {$[0.87,0.93]$} & $<.001$ & 35.40 & 1.08 \\
\hline Child gender & & & -.02 & .10 & .97 & {$[0.81,1.20]$} & .875 & .03 & 1.00 \\
\hline Child disability & & & .02 & .12 & 1.02 & {$[0.80,1.29]$} & .904 & .02 & 1.07 \\
\hline Parent age at birth of child & & & -.02 & .01 & .99 & {$[0.98,1.02]$} & .456 & .08 & 1.09 \\
\hline Parent marital status & & & .12 & .15 & 1.13 & {$[0.85,1.51]$} & .400 & .71 & 1.07 \\
\hline Parent education & & & & & & & $<.001$ & 19.68 & 1.23 \\
\hline Parent education (1) & & & .60 & .15 & 1.82 & {$[1.36,2.44]$} & $<.001$ & 16.20 & \\
\hline Parent education (2) & & & .38 & .11 & 1.46 & {$[1.17,1.83]$} & .001 & 11.27 & \\
\hline Parent employment & & & & & & & .007 & 12.04 & 1.11 \\
\hline Parent employment (1) & & & -.25 & .25 & .79 & {$[0.49,1.25]$} & .297 & 1.12 & \\
\hline Parent employment (2) & & & .09 & .25 & 1.09 & {$[0.66,1.79]$} & .738 & .11 & \\
\hline Parent employment (3) & & & .13 & .25 & 1.14 & {$[0.70,1.86]$} & .600 & .28 & \\
\hline Income inadequacy & & & -.33 & .12 & .72 & {$[0.57,0.91]$} & .007 & 7.39 & 1.11 \\
\hline Block 2 & .11 & .04 & & & & & & & \\
\hline Child behaviour & & & .04 & .01 & 1.04 & {$[1.03,1.05]$} & $<.001$ & 61.23 & 1.09 \\
\hline Block 3 & .50 & .39 & & & & & & & \\
\hline Attitudes & & & 1.40 & .07 & 4.60 & {$[3.57,4.60]$} & $<.001$ & 468.66 & 1.06 \\
\hline
\end{tabular}

Note. $\mathrm{CI}=$ confidence interval for odds ratio $(O R) . \mathrm{VIF}=$ variance inflation factor.

\section{Block 1}

Among the demographic child characteristics, the pattern found in the logistic regression mirrored the findings of bivariate analyses. The younger the child, the more likely the parent was to report spanking that child (odds ratio $[O R]=.91, p<.001)$. However, neither child gender $(O R=.99, p=.875)$ nor child disability status $(O R=1.02, p=.904)$ were significantly associated with self-reported spanking.

Among the demographic parent characteristics, the pattern found in the logistic regression was consistent with the pattern found in bivariate analyses for most variables. Parent marital status was not significantly associated with self-reported spanking $(O R=1.13, p=.400)$. Whether parents were married/cohabitating or whether they were single had no significant association with the likelihood that they would report spanking their child. Parent education level was significantly (Wald $=19.68, p<.001$ ) associated with self-reported spanking. Parents whose reported level of education was high school or less were more likely to report 
spanking than were parents who had attended trade or technical school. Further, parents who had attended university were less likely to report spanking than parents who had attended trade or technical school. Similarly, there was a significant association between spanking and parent employment (Wald $=12.04$, $p=.007)$. However, parents who reported not working for pay were no more likely to report spanking than were parents who were working for pay, either full-time or part-time. Consistent with the pattern shown in bivariate analyses, inability to meet essential expenses showed a significant relationship with self-reported spanking $(O R=.72, p=.007)$. Parents who said that there was at least one time in the previous 12 months when household income was not enough to meet essential expenses were more likely to report spanking than were parents who indicated that their family income was adequate in meeting essential expenses throughout the previous 12 months. In contrast to the bivariate analyses, parent age at the birth of the target child was not significantly associated with reported spanking $(O R=1.00, p=.777)$.

\section{Block 2}

Over and above the effects of the demographic variables, child behaviour was significantly associated with self-reported spanking $(O R=1.04, p<.001)$. The more problematic a parent rated the child's behaviour, the more likely he or she was to report spanking in the last month. All variables that had significant relationships with spanking in Block 1 still had significant relationships in Block 2, after the addition of child behaviour to the regression model.

\section{Block 3}

Spanking attitudes were significantly associated with self-reported spanking $(O R=4.05, p<.001)$. The greater the extent to which parents endorsed pro-spanking attitudes, the more likely they were to report spanking. This model yielded correct classification of $82.9 \%$ of the sample $(91.6 \%$ of parents who did not report spanking and $57.1 \%$ of parents who did report spanking). Of the variables that had significant relationships with spanking in Block 2, only child age and child behaviour still had significant relationships in Block 3, after the addition of spanking attitudes to the regression model.

\section{DISCUSSION}

Using data collected in 2012-2013, we found that 25.4\% of the Canadian parents in this sample reported spanking their child in the previous month. This finding is comparable to Statistics Canada (2009) data which show that nearly one quarter of Canadian parents of children aged 2-11 years reported physically punishing their child.

Consistent with previous studies (e.g., Day et al., 1998; Giles-Sims et al., 1995; Regalado et al., 2004), we found that the younger the child, the more likely the parent was to report spanking. Given the consistent replication of this finding, we conclude that younger children are at a greater risk for being spanked than are older children.

In our analyses, we found that child gender was not associated with spanking. It is possible that the gender differences that were found by Day et al. (1998) have diminished over the years. That is, it is possible 
that in the past, parents were less likely to spank daughters, but now-despite overall declines in rates of spanking - they are not any less likely to spank a female child than they are to spank a male child. Our finding that a child's disability status had no significant influence on the likelihood that the parent would report spanking is counter to that of the only other study to have examined the association between spanking and child disability status by Regalado et al. (2004). It is possible that the discrepancy is due to the broader definition of disability used in this study, which included chronic illness, a physical disability, or intellectual disability; by contrast, Regalado et al. used The Parents' Evaluation of Developmental Status (PEDS; Glascoe, 1998). Further research should evaluate the association between spanking and child disability status. More detailed conceptualizations of disability may help to inform whether spanking is related to disability type.

We did not find parent age at birth of the child to be a significant predictor of spanking. This is contrary to the findings of both Regalado et al. (2004), who examined parents' current age, and Wissow (2001), who examined parent age at the child's birth. The discrepancy with findings from this sample may be accounted for by differences in the ages of the children, as Regalado et al. (2004) and Wissow (2001) employed samples of parents of children aged 0-4 years. There are potential confounds between child age and the number of children a parent has. As parents become more experienced, they may be less likely to spank children who fall later in the birth order.

Consistent with both Wissow (2001) and Giles-Sims et al. (1995), we found that marital status was not significantly related to self-reported spanking. Our significant finding related to education is inconsistent with the findings of both Giles-Sims et al. (1995) and Regalado et al. (2004), who did not find significant associations between parent education and their self-reported spanking. However, Giles-Sims et al. (1995) only sampled mothers (of children aged 3-10 years) and used analysis of variance as opposed to logistic regression. Regalado et al. (2004) sampled only parents of children aged 4-35 months and used chi-square analyses. These differences in samples and analyses could explain the discrepancy between findings. This significant relationship could be explained by a greater awareness of child development trajectories and the harms of physical punishment among parents with higher levels of education.

Similar to our finding on education, we found the related construct of employment to be significantly related to reported spanking. This finding is inconsistent with that of Giles-Sims et al. (1995), whose analysis involved more than one target child. However, although we obtained an effect for employment status, the comparisons between different categories of employment status did not reach statistical significance. Another related construct, income inadequacy, was also found to have a significant relationship with spanking. Our finding that parents whose income was inadequate to pay for essential expenses at least once in the past 12 months are more likely to report spanking their child is consistent with the findings of Giles-Sims et al. (1995) and Wissow (2001), who both found that lower income was associated with reported spanking. It is possible that increased spanking by parents of lower income could be influenced by increased levels of finance-related stress.

We found that parents who reported spanking their child rated the child as having a higher degree of problematic behaviour than did parents who did not report spanking. This finding adds to a large body of literature that has reached similar conclusions (Berlin et al., 2009; Lee et al., 2013; MacKenzie et al., 2011; Maguire-Jack et al., 2012; Stormshak et al., 2000). However, the direction of the relationship between child 
behaviour problems and reported spanking remains unclear. Research has not clearly delineated whether behaviour problems lead to spanking or whether spanking itself leads to behaviour problems.

Of all variables examined, we found attitudes toward spanking to have the strongest association with reported spanking. Similarly, Ateah and Durrant (2005) found pro-spanking attitudes to be the best predictor of whether a parent reports actually spanking his or her child. Many others (e.g., Durrant et al., 2003; Pinderhughes et al., 2000; Zolotor \& Puzia, 2010) have found the same relationship in their work. This finding is not surprising given that we would expect someone who endorses a behaviour to be likely to report said behaviour.

\section{Limitations}

There are some limitations to this study that should be taken into account when interpreting the results. The item used to assess self-reported spanking referred to "spanking/smacking." Some participants may have perceived these words to have different meanings. Second, even though the study was completed anonymously, some parents may have been reluctant to report spanking their child. Third, although there is some ethnic diversity in the sample as well as a considerable number of fathers, the sample itself is not representative of the Canadian population.

\section{Practice Implications}

There are important practice implications stemming from this study. Based on the variables that we found to be associated with self-reported spanking, public health program administrators can identify who may be most in need of programs that promote positive parenting techniques as an alternative to spanking. Further, our findings can inform public health interventions by assisting administrators in identifying groups of individuals who are most likely to be engaging in spanking. Our finding related to the significance of attitudes suggests that programs aimed at changing spanking-related attitudes may be helpful across a diverse demographic sample.

It is most encouraging to note that the rate of spanking that we have identified is among the lowest in any North American spanking-related study. This is likely reflective of a societal trend toward disapproval of physical punishment and, in turn, lower levels of physical punishment. Despite the focus of this study in identifying spanking-related risk factors, researchers and clinicians should not lose sight of changing attitudes and practices in relation to child physical punishment.

\section{REFERENCES}

Ateah, C. A., \& Durrant, J. (2005). Maternal use of physical punishment in response to child misbehavior: Implications for child abuse prevention. Child Abuse and Neglect, 29, 177-193.

Ateah, C. A., \& Parkin, C. M. (2002). Childhood experiences with, and current attitudes toward, corporal punishment. Canadian Journal of Community Mental Health, 21, 35-46.

Bell, T., \& Romano, E. (2012). Opinions about child corporal punishment and influencing factors. Journal of Interpersonal Violence, 27, 2208-2229. 
Berlin, L. J., Ispa, J. M., Fine, M. A., Malone, P. S., Brooks-Gunn, J., Brady-Smith, C., Ayoub, C., \& Bai, Y. (2009). Correlates and consequences of spanking and verbal punishment for low-income White, African-American, and Mexican-American toddlers. Child Development, 80, 1403-1420.

Clément, M.-È., Bernèche, F., Chamberland, C., \& Fontaine, C. (2013). Enquête sur la violence familiale dans la vie des enfants du Québec 2012. Les attitudes parentales et les pratiques familiales. Québec: Institut de la statistique du Québec.

Criminal Code of Canada. (2008). Section 43. Retrieved from the Parliament of Canada website http://www.parl.gc.ca/ content/lop/researchpublications/prb0510-e.htm

Day, R., Peterson, G., \& McCracken, C. (1998). Predictors of frequent spanking of younger and older children. Journal of Marriage and the Family, 60, 79-94.

Durrant, J., \& Ensom, R. (2012). Physical punishment of children: Lessons from 20 years. Canadian Medical Association Journal, 184(12), 1373-1377.

Durrant, J. E., Rose-Krasnor, L., \& Broberg, A. G. (2003). Maternal beliefs about physical punishment in Sweden and Canada. Journal of Comparative Family Studies, 34, 586-604.

Faruggia, S. (2009). Parenting belief questionnaire. Unpublished manual, University of Auckland.

Ferguson, C. J. (2013). Spanking, corporal punishment and negative long-term outcomes: A meta-analytic review of longitudinal studies. Clinical Psychology Review, 33, 196-208.

Fréchette, S., \& Romano, E. (2012, April). Change in the use of corporal punishment and other disciplinary strategies over a 14-year period in a representative sample of Canadian parents. Paper presented at the Society for Research in Child Development Biennial Conference, Seattle, Washington.

Gagné, M. H., Tourigny, M., Joly, J., \& Pouliot-Lapointe, J. (2007). Predictors of adult attitudes toward corporal punishment of children. Journal of Interpersonal Violence, 22, 1285-1304.

Gershoff, E. T. (2002). Corporal punishment by parents and associated child behaviours and experiences: A meta-analytic and theoretical review. Psychological Bulletin, 128, 539-579.

Gershoff, E. T., Lansford, J. E., Sexton, H. R., Davis-Kean, P. E., \& Sameroff, A. J. (2012). Longitudinal links between spanking and children's externalizing behaviors in a national sample of White, Black, Hispanic, and Asian American families. Child Development, 83, 838-843.

Giles-Sims, J., Straus, M. A., \& Sugarman, D. B. (1995). Child, maternal, and family characteristics associated with spanking. Family Relations, 44, 170-176.

Glascoe, F. P. (1998). The value of parents' evaluations of developmental status in detecting and addressing children's developmental and behavioral problems. Assessment for Effective Intervention, 23, 185-203.

Global Initiative to End the Corporal Punishment of Children. (2013). Supporters. Retrieved from http://www.endcorporalpunishment.org/pages/frame.html

Grogan-Kaylor, A., \& Otis, M. D. (2007). The predictors of parental use of corporal punishment. Family Relations, 56, 80-91.

Holden, G. W., Coleman, S. D., \& Schmidt, K. L. (1995). Why 3-year-old children get spanked: Parent and child determinants in a sample of college-educated mothers. Merrill-Palmer Quarterly, 41(4), 431-452.

Jamal, F., Dufour, S., Clément, M.-Ė., \& Chamberland, C. (2011). Lien entre légitimité perçue de la violence subie dans l'enfance et comportements violents à l'égard des enfants selon les pères québécois. Revue de Psychoéducation, 40, 175-190.

Lansford, J. E., Wager, L. B., Bates, J. E., Dodge, K. E., \& Pettit, G. E. (2012). Parental reasoning, denying privileges, yelling, and spanking: Ethnic differences and associations with child externalizing behaviour. Parenting: Science and Practice, 12, 42-56.

Larzelere, R. E., Cox, R. B., \& Smith, G. L. (2010). Do nonphysical punishments reduce antisocial behavior more than spanking? A comparison using the strongest previous causal evidence against spanking. BMC Pediatrics, 10, 1-17.

Lee, C. M., Smith, P. B., Stern, S. B., Piche, G., Feldgaier, S., Ateah, C., ... Chan, K. (2014). The International Parenting Survey-Canada: Exploring access to parenting services. Canadian Psychology, 55, 110-116.

Lee, S. J., Taylor, C. A., Altschul, I., \& Rice, J. C. (2013). Parental spanking and subsequent risk for child aggression in father-involved families of young children. Children and Youth Services Review, 35, 1476-1485.

MacKenzie, M. J., Nicklas, E., Brooks-Gunn, J., \& Waldfogel, J. (2011). Who spanks infants and toddlers? Evidence from the fragile families and child well-being study. Children and Youth Services Review, 33, 1364-1373. 
Maguire-Jack, K., Gromoske, A. N., \& Berger, L. M. (2012). Spanking and child development during the first 5 years of life. Child Development, 83, 1960-1977.

Morawska, A., \& Sanders, M. R. (2010). The child adjustment and parent efficacy scale (CAPES). Brisbane: Parenting and Family Support Centre.

Mulvaney, M. K., \& Mebert, C. J. (2007). Parental corporal punishment predicts behavior problems in early childhood. Journal of Family Psychology, 21, 389.

Pinderhughes, E. E., Dodge, K. A., Bates, J. E., Pettit, G. S., \& Arnaldo, Z. (2000). Discipline responses: Influences of parents' socioeconomic status, ethnicity, beliefs about parenting, stress, and cognitive-emotional processes. Journal of Family Psychology, 14, 380-400.

Regalado, M., Sareen, H., Inkelas, M., Wissow, L. S., \& Halfon, N. (2004). Parents' discipline of young children: Results from the national survey of early childhood health. Pediatrics, 113, 1952-1958.

Sanders, M. R., Morawska, A., Haslam, D. M., Filus, A., \& Fletcher, R. (2014). Parenting and family adjustment scales (PAFAS): Validation of a brief parent-report measure for use in assessment of parenting skills and family relationships. Child Psychiatry \& Human Development, 45, 255-272.

Statistics Canada. (2009). National longitudinal survey of children and youth. Retrieved from http://www23.statcan. gc.ca/imdb/p2SV.pl?Function=getSurvey\&SDDS=4450\&Item_Id=25609\&lang=en

Statistics Canada. (2012a). Portrait of families and living arrangements in Canada: Families, households and marital status, 2011 census of population. Retrieved from http://www12.statcan.gc.ca/census-recensement/2011/as-sa/98312-x/98-312-x2011001-eng.pdf

Statistics Canada. (2012b). French and the francophonie in Canada: Language, 2011 census of population. Retrieved from http://www12.statcan.gc.ca/census-recensement/2011/as-sa/98-314-x/98-314-x2011003_1-eng.cfm

Stormshak, E. A., Bierman, K. L., McMahon, R. J., \& Lengua, L. J. (2000). Parenting practices and child disruptive behaviour problems in early elementary school. Journal of Clinical Child Psychology, 29, 17-29.

Straus, M. A., \& Donnelly, D. A. (1993). Corporal punishment of adolescents by American parents. Youth \& Society, $24,419-442$.

Tabachnick, B. G., \& Fidell, L. S. (2007). Using multivariate statistics (5th ed.). New York: Allyn and Bacon.

UNICEF Innocenti Research Centre. (2012). Measuring child poverty: New league tables of child poverty in the world's rich countries. Innocenti Report Card 10. Florence: Author.

Vittrup, B., Holden, G. W., \& Buck, J. (2006). Attitudes predict the use of physical punishment: A prospective study of the emergence of disciplinary practices. Pediatrics, 117, 2055-2064.

Wissow, L. S. (2001). Ethnicity, income, and parenting contexts of physical punishment in a national sample of families with young children. Child Maltreatment, 6, 118-129.

Zolotor, A. J., Theodore, A. D., Runyan, D. K., Chang, J. J., \& Laskey, A. L. (2011). Corporal punishment and physical abuse: Population-based trends for three-to-11-year-old children in the United States. Child Abuse Review, 20, 57-66.

Zolotor, A. J., \& Puzia, M. E. (2010). Bans against corporal punishment: A systematic review of the laws, changes in attitudes and behaviour. Child Abuse Review, 19, 229-247. 